\title{
Pulmonary Lymphangioleiomyomatosis: A Rare Case
}

\section{Pulmoner Lenfanjioleiomyomatozis: Nadir Bir Olgu}

\author{
Yetkin AĞAÇKIRAN' ${ }^{\text {, Arzu ERTÜRK² }}$, Fatma İrem YEŞiLLER², Nevin Taci HOCA², Leyla Nesrin ÜSTÜN, \\ Nermin ÇAPAN ${ }^{2}$
}

Department of ${ }^{1}$ Pathology, ${ }^{2}$ Chest Diseases and ${ }^{3}$ Chest Surgery, Atatürk Chest Diseases and Chest Surgery Training and Research Hospital , ANKARA, TURKEY

\begin{abstract}
Lymphangioleiomyomatosis is an uncommon lung disease primarily affecting women of childbearing age. It is characterized by the progressive proliferation and infiltration of smooth muscle-like cells, which lead to cystic destruction of the lung parenchyma; obstruction of airways, blood vessels, and lymphatics; and loss of pulmonary function. We present the case of a 46-year-old female patient with chest pain, cough, sputum, and dyspnea on exertion for three weeks. Minimal pneumothorax was noted, and the patient was referred to our center for further investigation and treatment. High-resolution computed tomography revealed numerous bilateral thin-walled air cysts and interstitial thickening affecting the central and peripheral part of the upper zone of the lung. We performed an open-lung biopsy to confirm lymphangioleiomyomatosis. Our aim is to discuss the pathogenesis and other lesions noted in the differential diagnosis of this rare disease.
\end{abstract}

Key Words: Lymphangioleiomyomatosis, Immunohistochemistry, Lung neoplasms, Differential diagnosis

\section{INTRODUCTION}

Lymphangioleiomyomatosis (LAM) is an uncommon lung disease primarily affecting women of childbearing age. It is characterized by the progressive proliferation and infiltration of smooth muscle-like cells (LAM cells), which lead to the cystic destruction of the lung parenchyma; obstruction of airways, blood vessels, and lymphatics; and loss of pulmonary function (1). In 1966, Cornog and Enterline first described what they termed lymphangiomyoma; subsequent literature used different terminologies (2). The coexpression of contractile proteins and melanocytic markers with proliferating LAM cells suggests it originates in perivascular epithelioid cells (PECs). However, the definite origin of LAM cells is still uncertain $(2,3)$.

\section{CASE REPORT}

A 46-year-old female patient presented with cough, sputum persisting for a year, and dyspnea on exertion for three

(Turk Patoloji Derg 2014, 30:233-236)

Received : 30.05.2011 Accepted : 28.06.2011

\section{ÖZ}

Pulmoner lenfanjioleiomyomatozis primer olarak reprodüktif dönem kadınları etkileyen nadir görülen bir hastalıktır. Düz kas benzeri immatür hücrelerin progressif proliferasyonu ve infiltrasyonuyla karakterizedir, akciğer parankiminde kistik destrüksiyona yol açarak havayolu kan damarları ve lenfatiklerde obstrüksiyon ve pulmoner fonksiyon kaybına neden olur. Burada, öksürük, balgam çıkarma ve 3 haftadır eforla artan nefes darlığı yakınması ile başvuran 46 yaşındaki kadın hastayı sunuyoruz. Sınırlı pnömotoraks saptanan hasta, ileri tetkik ve tedavi amacıyla merkezimize yönlendirilmiştir. Yüksek rezolüsyonlu bilgisayarlı tomografi'de her iki akciğerde üst zonlarda belirginleşen, santrali ve periferi etkileyen çok sayida hava kistleri ve interstisiyel kalınlaşmalar saptandı. Açık akciğer biyopsisi ile lenfanjioleiomyomatozis tanısı teyit edildi. Bu nadir olguyu patogenezi ve ayırıcı tanıda yer alan diğer lezyonları tartışmak için sunuyoruz.

Anahtar Sözcükler: : Lenfanjioleiomyomatozis, İmmünohistohimya, Akciğer tümörleri, Ayırıcı tanı

weeks. The patient reported to the physician with cough, and antibiotics were prescribed with no improvement in symptoms. A chest CT taken at a later date revealed minimal pneumothorax. She was referred to us for further investigation and treatment. She was admitted for differential diagnosis of minimal pneumothorax, interstitial lung disease, and LAM. Routine tests were conducted, and the pulmonary function test (PFT) revealed FVC: 96\%, FEV1: 68\%, FEV1/FVC: 61\%, and DLCO: $27 \%$. Nasal oxygen and bronchodilator treatment was started. There was no al-antitrypsin deficiency, and collagen markers were negative. The thoracic surgery department was consulted, oxygen treatment and follow-up with a PA chest $\mathrm{x}$-ray was suggested, and no chest tube was indicated. High-resolution computed tomography (HRCT) revealed numerous bilateral thin-walled air cysts and interstitial thickening affecting the central and peripheral part of the upper zone of the lung (Figure 1). An ultrasound of the abdomen revealed a $6 \times 2.5 \mathrm{~cm}$ lobulated contoured-

Correspondence: Yetkin AĞAÇKIRAN

Atatürk Gögüs Hastalıkları ve Gögüs Cerrahisi Eğitim ve Araştırma

Hastanesi, Patoloji Bölümü, ANKARA, TURKEY

E-mail: yagackiran@hotmail.com Phone: +90 5327280628 
walled cystic lesion around the umbilicus in the right lower paraaortic region. Past history of a subtotal hysterectomy and left utero-salphingo-oopherectomy operation for uterine leiomyoma in June 2010 was noted. Tumor markers of the reproductive organs were negative, and transbronchial biopsy with FOB was non-specific. A diagnostic open-lung biopsy was performed.

Macroscopically, the specimen from the left lower lobe was $4 \times 2.5 \times 1.5 \mathrm{~cm}$ and from the upper lobe was $4 \times 1.8 \times 1.5 \mathrm{~cm}$, both with cystic features on the cut surface (Figure 2).

On microscopic examination, proliferating LAM cells, heterogeneous epithelioid and spindle-shaped immature muscle-like proliferating cells, were found in the cystic space of thelungparenchyma(Figure3).Animmunohistochemical stain was positive for contractile proteins (smooth muscle actin and desmin), the melanocytic marker HMB-45 (Figure 4), estrogen receptor (ER), progesterone receptor (PR), and CD56 in the LAM cells. Pan cytokeratin, EMA, CEA, S-100 protein, chromogranin, and CD34 stains were negative. The Ki-67 proliferation index was $1 \%$.

\section{DISCUSSION}

The most frequently stated first clinical sign was spontaneous pneumothorax (37.5\%). Typically, LAM is a disease of women of childbearing age and worsens during pregnancy and following the administration of estrogens. The mean age at disease onset is 38.9 years and at diagnosis 41.0 years. The global prevalence of pulmonary LAM is unknown and is estimated at approximately 1 to 5 of $10^{6}$ women (2). LAM occurs in two main forms: tuberous sclerosis complex (TSC)-associated LAM and sporadic LAM (S-LAM). Most LAM cases are sporadic, and S-LAM represents about 85\% of the patients. In these cases, there is no or little mutation in the TSC1 or TSC2 gene, whereas in the sclerosis complex (TSC) autosomal-dominant genetic disease, the TSC1 or TSC2 gene is frequently affected. Compared to patients with TSC1 mutations, patients with TSC2 mutations have a higher cystic-formation rate $(2,4)$.

The TSC1 gene is located on the long arm of chromosome 9 (9q34) and encodes the protein hamartin $(130 \mathrm{kDa})$, whereas TSC2 is located on the short arm of chromosome 16 (16p13.3) and encodes the protein tuberin (198 kDa) (24). Mutations in TSC1 and TSC2 genes cause LAM cells to exhibit features of coexpression contractile proteins (smooth muscle actin and desmin) and melanocytic markers (HMB45, HMSA-1, Melan-A/MART-1). This suggests this lesion should be considered a deficiency or dysfunction of the encoded proteins hamartin or tuberin, respectively, which is believed to constitute activation of mTOR, leading to

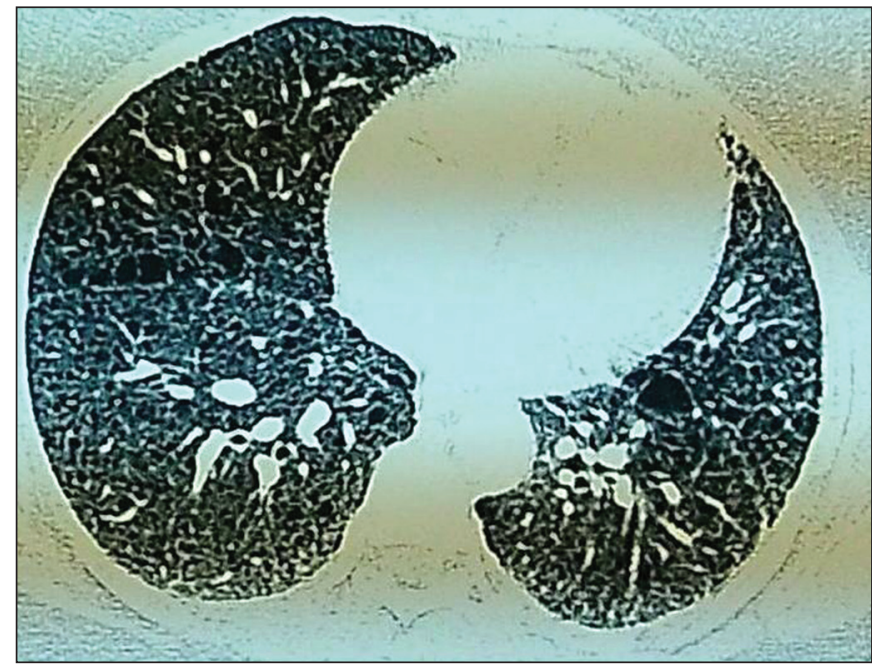

Figure 1: Thorax High-resolution computed tomography showing a uniform multiple air cyst and interstitial thickening.

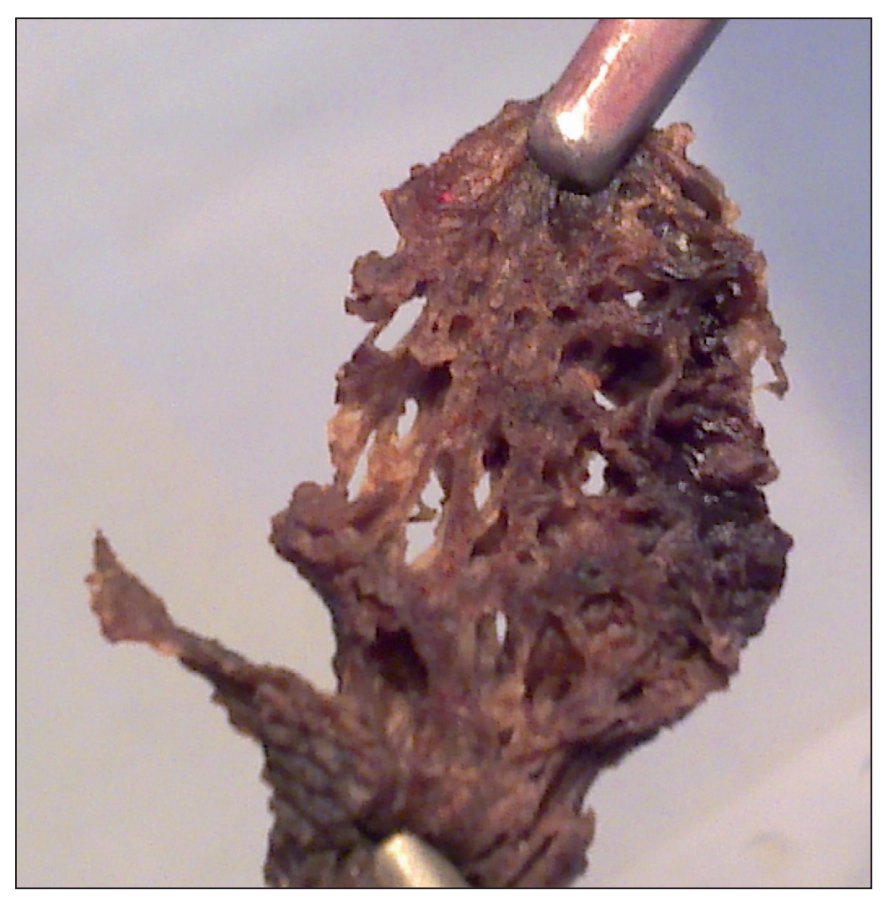

Figure 2: Macroscopically, we notice diffuse cystic changes in the lung parenchyma.

increased protein translation and, ultimately, inappropriate cellular proliferation, migration, and invasion (2). LAM cells are suggested to be of perivascular epithelioid cell origin. However, the origin of LAM cells is still unclear. In addition to contractile proteins and melanocytic markers, there have been reports in the literature demonstrating other positive markers such as CD1a (2), CD63, PNL2 (3), cathepsin-k (5), B7-H3 (6), and the presence of estrogen receptor (ER) and progesterone receptor (PR) in $50 \%$ of epithelioid LAM cells (2). 


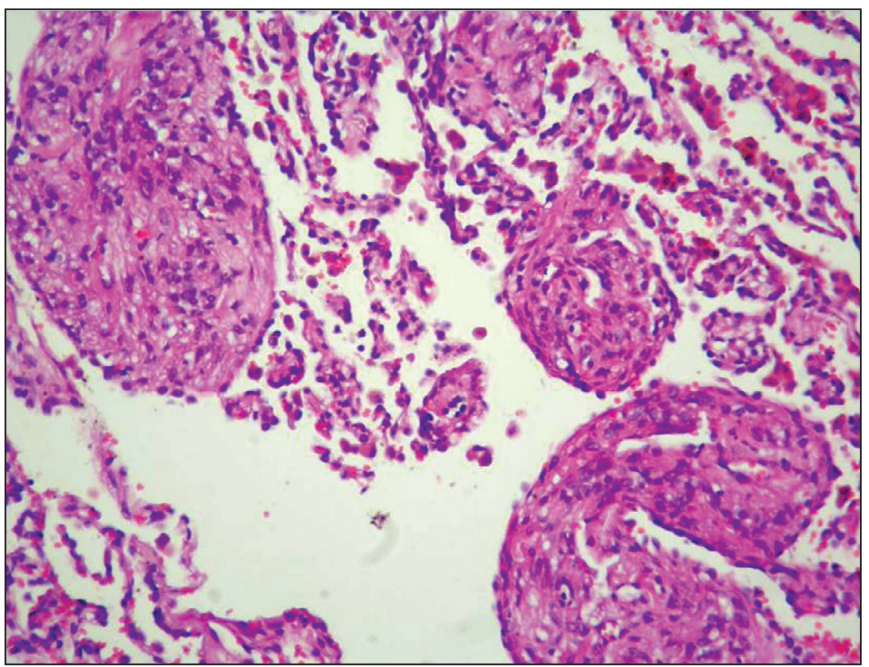

Figure 3: Heterogeneous epithelioid and spindle-shaped immature muscle-like proliferation cells in the cystic space of the lung parenchyma (H\&E; x200).

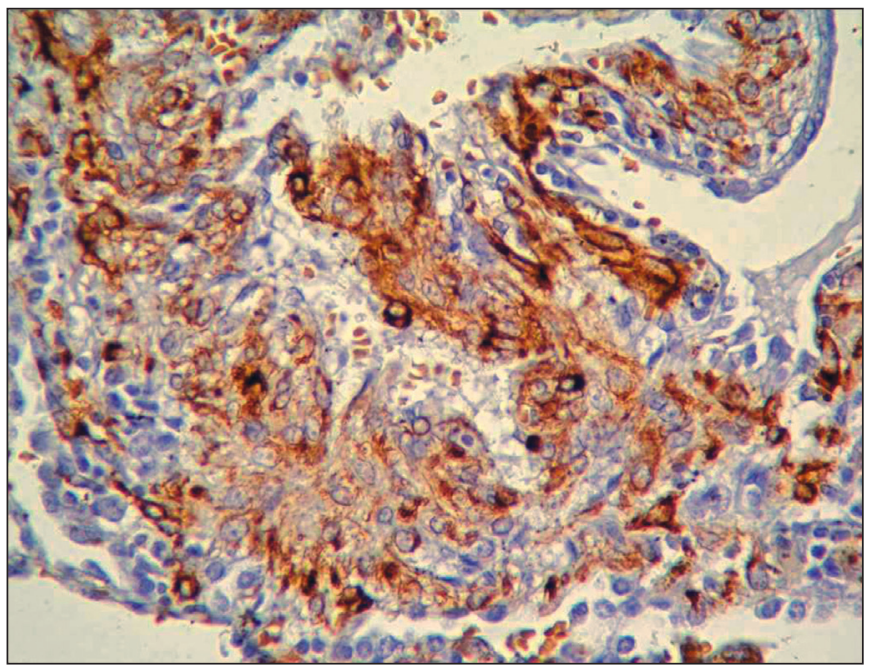

Figure 4: The positive stain of $\mathrm{HMB}-45$ prominent in the epithelioid cells (immunoreactivity; x400).

In our case, during the differential diagnosis, we noticed CD56 expression; so far, no studies in the literature have examined this marker in LAM cases. A large series is required to verify the reliability of this antibody. A study of CD56 in soft tissue tumors revealed positivity in the gastrointestinal and uterine smooth muscle cells but negativity in the vascular smooth muscle cells and normal skeletal striated muscle cells (7).

Initially, LAM cells were believed to originate from either the airway or vascular smooth muscle cells, but this hypothesis is not supported by the diffuse existence of LAM cells throughout the lungs and the irregular distribution within the nodules, without the formation of organized layers. Another hypothesis-based on some clinical, genetic, and cell culture studies-is that LAM cells may originate from angiomyolipomas and be brought into the lungs. However, about one-third of S-LAM cases are without angiomyolipomas, and in such cases, LAM cell origin cannot be explained by metastatic or neoplastic cell dissemination. Another hypothesis about the origin of LAM cells is that they begin as donor cells from a nonhost source. The source of non-host cells could be an organ donor, a blood transfusion, or fetal cells persisting in maternal circulation. Evidence for the non-host cell theory remains elusive $(1,2)$. Recent studies on angiolipomas, a PEC-cell-associated group of tumors, showed positive neural stem cell markers for NG2 and L1, suggesting these cells (PECs) may originate from defective differentiating precursor stem cells (8). We believe a large LAM series study on NG2 and L1 antibodies would enlighten us on the histogenesis of the defective differentiating precursor stem cells. Unfortunately, the origin of these cells is still uncertain.

During the early stages of the disease, it is easy to misdiagnose LAM cells that infiltrate as normal or emphysematous (2). Benign metastasizing leiomyoma is not usually associated with cysts, and the nodules of smooth muscle are generally larger than those seen in LAM. Patients always have a history of uterine leiomyoma, and the smooth muscle cells are negative for melanocytic markers, such as HMB-45 and Melan-A (9). Langerhans cell histiocytosis can present with cyst formation radiographically; however, the predilection of the small nodules or nodules with cystic changes in the mid- and upper-lung zones and the infiltrating Langerhans cell (positive for CD1a, S100, and langerin) and eosinophils will differentiate it from LAM. Diffuse pulmonary lymphangiomatosis shows diffuse proliferation of lymphatic vascular spaces and smooth muscles, mimicking LAM. The disease usually affects children of either sex rather than women of childbearing age. Compared with LAM, the smooth muscle proliferation is less marked, without extension into the alveoli or cyst formation, and is negative for HMB-45 staining. Minute pulmonary meningothelial nodules are lesions histologically composed of small nests of epithelioid meningothelial cells positive for EMA but negative for HMB-45 (2). In diffuse pulmonary neuroendocrine cell hyperplasia, epithelial markers like CEA and neuroendocrine markers like chromagranin are positive (10). In multifocal micronodular pneumocyte hyperplasia, EMA, cytokeratin, and surfactant apoprotein $A$ and $B$ are positive, whilst HMB-45, smooth muscle actin, desmin, CEA, ER, PR, and p53 are negative $(11,12)$. 
Treatment of LAM involves several hormone-based treatments, such as bilateral oophorectomy, gonadotropinreleasing hormone agonists, tamoxifen, or progesterone. Inhaled bronchodilator therapy may provide symptomatic relief. Lung transplantation has been accepted as therapies for end-stage pulmonary LAM. Novel macrolide agent sirolimus (rapamycin), acting as an mTOR inhibitor, has shown promising results in the treatment of LAM. Other therapeutic targets-such as MMP inhibition by an MMP inhibitor (doxycycline), Rhed GTPase inhibition by 3-hydroxy-3-methylglutaryl-coenzyme A inhibitors (statins), or JAK-STAT3 pathway inhibition by interferon- $\gamma$-may also have potential for the treatment of LAM (13). We used hormone-based tamoxifen citrate 20 $\mathrm{mg}$, administered twice daily, on our patient. The prognosis of the disease varies. The five-year survival rate is between 50 and $97 \%$.

We present this rare case to emphasize the pathogenesis and the differential diagnosis of LAM, especially in the early stage of the disease when lesions may be considered normal or the result of emphysematous changes.

\section{REFERENCES}

1. Krymskaya VP. Smooth muscle-like cells in pulmonary lymphangioleiomyomatosis. Proc Am Thorac Soc. 2008;5: 119-26.

2. Zhang X, Travis WD. Pulmonary lymphangioleiomyomatosis. Arch Pathol Lab Med. 2010;134:1823-28.

3. Zhe X, Schuger L. Combined smooth muscle and melanocytic differentiation in lymphangioleiomyomatosis. J Histochem Cytochem. 2004;52:1537-42.

4. Nasir K, Ahmad A. Giant renal angiomyolipomas and pulmonary lymphangiomyomatosis. Saudi J Kidney Dis Transpl. 2010;21: 314-9.
5. Chilosi M, Pea M, Martignoni G, Brunelli M, Gobbo S, Poletti V, Bonetti F. Cathepsin-k expression in pulmonary lymphangioleiomyomatosis. Modern Pathology. 2009;22:161-6.

6. Boorjian SA, Sheinin Y, Crispen PL, Lohse CM, Leibovich BC, Kwon ED. T-cell co-regulatory molecule expression in renal angiomyolipoma and pulmonary lymphangioleiomyomatosis. Urology. 2009;74:1359-64.

7. Miettinen M, Cupo W. Neural cell adhesion molecule distribution in soft tissue tumors. Hum Pathol. 1993;24:62-6.

8. Lim SD, Stallcup W, Lefkove B, Govindarajan B, Au KS, Northrup H, Lang D, Fisher DE, Patel A, Amin MB, Arbiser JL. Expression of the neural stem cell markers NG and L1 in human angiomyolipoma: Are angiomyolipomas neoplasms of stem cells? Mol Med. 2007;13:160-5.

9. Kayser K, Zink S, Schneider T, Dienemann H, André S, Kaltner H, Schüring MP, Zick Y, Gabius HJ. Benign metastasizing leimyoma of the uterus: Documentation of clinical, immunohistochemical and lectin-histochemical data of ten cases. Virchows Arch. 2000;437:284-92.

10. Coletta EN, Voss LR, Lima MS, Arakaki JS, Câmara J, D’Andretta Neto C, Pereira CA. Diffuse idiopathic pulmonary neuroendocrine cell hyperplasia accompanied by airflow obstruction. J Bras Pneumol. 2009;35:489-94.

11. Shintani Y, Ohta M, Iwasaki T, Ikeda N, Tomita E, Nagano T, Kawahara K. A case of micronodular pneumocyte hyperplasia diagnosed through surgical resection. Ann Thorac Cardiovasc Surg. 2010;16:45-7.

12. Kobashi Y, Sugiu T, Mouri K, Irei T, Nakata M, Oka M. Multifocal micronodular pneumocyte hyperplasia associated with tuberous sclerosis: Differentiation from multiple atypical adenomatous hyperplasia. Jpn J Clin Oncol. 2008;38:451-4.

13. Lu SH, Hou YY, Tan YS, Xu JF, Zeng HY, Sujie AK, Wang $\mathrm{XD}$, Bai CX. Clinical and histopathological alterations of lymphangioleiomyomatosis in 14 Chinese patients. Chinese Medical Journal. 2009;122:1895-900. 